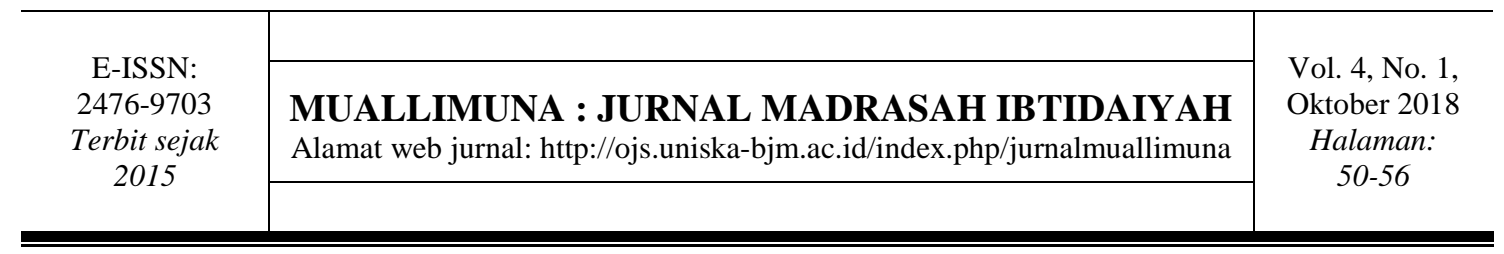

\title{
HUBUNGAN BERPIKIR KRITIS DAN MEMBACA PEMAHAMAN DENGAN KEMAMPUAN MENULIS ARGUMENTASI
}

\author{
Tutus Rani Arifa \\ Universitas Islam Kalimantan MAB Banjarmasin \\ tutusuniska17@gmail.com
}

\begin{abstract}
Abstrak: Penelitian ini bertujuan untuk mengetahui: hubungan antara berpikir kritis dan pemahaman bacaan dengan kemampuan menulis argumentasi. Subjek penelitian ini adalah siswa SDN 03, 04, 05, 07, 08 Kota Banyumudal Pemalang. Instrumen yang digunakan adalah tes esai dan rubrik keterampilan menulis argumentasi. Data penelitian dianalisis dengan teknik korelasi sederhana. Hasil penelitian menemukan bahwa: 1) berpikir kritis memiliki hubungan positif dengan hasil kemampuan menulis argumentasi dengan nilai $r=0,421$, koefesien determinasi 0,1772 , dan peresamaan regresi $\hat{Y}=15,106+$ $0,114 \mathrm{x}_{1}$ 2) membaca pemahaman memiliki hubungan positif dengan kemampuan menulis argumentasi dengan nilai $\mathrm{r}=0,439$, koefesien determinasi 0,1927 , dan persamaan regresi $\hat{Y}=13,18+0,516 \mathrm{X}_{2}, 3$ ) berpikir kritis dan membaca pemahaman secara bersamasama berhubungan positif dengan kemampuan menulis argumentasi dengan $r=0,559$, koefesien determinasi 0,3124, dan persamaan regresi ganda $\hat{\mathrm{Y}}=4,428+0,096 \mathrm{X}_{1}+0,445 \mathrm{X}_{2}$. Kesimpulan penelitian ini adalah berpikir kritis memberikan kontribusi yang lebih besar kepada kemampuan menulis argumen dibandingkan dengan pemahaman bacaan.
\end{abstract}

\section{Kata Kunci: keterampilan menulis argumentasi; berpikir kritis; membaca pemahaman; siswa Sekolah Dasar}

\section{THE RELATIONSHIP OF CRITICAL THINKING AND READING COMPREHENSION TOWARD ARGUMENTATIVE WRITING ABILITY}

\begin{abstract}
The aims of this study was to determine the relationship of critical thinking and reading comprehension toward the argumentative writing ability. The subjects of this study were students of SDN 03, 04, 05, 0708 Banyumudal City Pemalang. The instrument used is essay test and rubric of argumentation writing skills. Research data were analyzed with simple correlation techniques. The results of the study found that: 1) critical thinking has a positive relationship with the results of the ability to write arguments with a value of $r=0.421$, the determination coefficient 0.1772 , and the regression equation $\hat{Y}=15.106$ $+0.114 x 12$ ) reading comprehension has a positive relationship with the ability to write arguments with the value of $r=0.439$, the determination coefficient of 0.1927 , and the regression equation $\hat{Y}=13.18+0.516 X 2$, 3) critical thinking and reading comprehension together are positively related to the ability to write arguments with $r=$ 0.559 , the determination coefficient of 0.3124 , and the multiple regression equation $\hat{Y}=$ $4,428+0,096 X 1+0,445 X 2$. The conclusion of this study is that critical thinking contributes more to the ability to write arguments compared to reading comprehension.
\end{abstract}

Keywords: argumentation writing skills; critical thinking; reading comprehension; Elementary School students 


\section{PENDAHULUAN}

Negara Kesatuan Republik Indonesia (NKRI) terdiri dari 34 provinsi. Dengan wilayah yang luas dan memiliki struktur geografis dan kebudayaan yang sangat heterogen, serta berbagai bahasa daerah yang berbeda-beda. Perbedaan inilah yang menjadikan Negara Indonesia sebagai negara yang kaya akan budaya dan adat istiadat. Untuk melengkapi keberagaman tersebut, maka diperlukan suatu wadah dalam upaya mengisi kebutuhan suatu masyarakat yakni melalui dunia pendidikan. Dimana tujuan pendidikan adalah untuk menciptakan manusia yang berkualitas, berdaya saing, dan berkarakter sehingga memiliki pandangan yang luas untuk mencapai suatu cita-cita yang diharapkan serta mampu beradaptasi di berbagai lingkungan.

Dalam pendidikan, khususnya pendidikan dasar, bahasa memegang peranan penting dalam mengidentifikasi kemampuan siswa. Bahasa merupakan alat mengapresiasikan pemikiran dan perasaan. Dengan kata lain bahasa adalah suatu sistem lambang berupa bunyi, bersifat arbirter, digunakan oleh suatu seseorang untuk bekerjasama, berkomunikasi, dan mengidentifikasi diri. Sebagai suatu sistem, maka bahasa terbentuk oleh suatu aturan, kaidah, atau pola-pola tertentu, baik dalam bidang tata bunyi, tata bentuk kata, maupun kata kalimat. Bila aturan, kaidah, atau pola ini dilanggar, maka komunikasi dapat terganggu.( Abdul Chaer, 2011)

Seperti yang diungkapkan oleh Jujun S. Suryasumantri, tanpa mempunyai kemampuan berbahasa maka kegiatan berpikir secara sistematis dan teratur tidak mungkin dilakukan. Manusia tidak mungkin mengembangkan kebudayaannya tanpa kemampuan berbahasa.(Jujun S, 2005) Keunikan inilah yang membedakan antara manusia dengan mahluk Tuhan lainnya.

Dihubungkan peran bahasa dalam kehidupan sehari-hari sebagai sarana komunikasi begitu juga dengan peran bahasa didalam pembelajaran Bahasa Indonesia, yang terdapat empat aspek kemampuan bahasa yakni menyimak, berbicara, membaca, dan menulis. Diantara empat kemampuan tersebut, kemampuan menulis merupakan kemampuan terakhir yang harus dikuasai oleh anak. Sejak anak lahir, ia memiliki kemampuan mendengar. Selanjutnya, dari kemampuan mendengarkan anak belajar berbicara sehingga memiliki kemampuan berbicara. Setelah itu, anak belajar membaca dari kata-kata yang ia lihat dan dengar. Selanjutnya, anak belajar untuk menulis yang merupakan kemampuan terakhir yang harus dimiliki anak.

Menurut Bell dan Burnaby dalam Ghazali, berpendapat bahwa menulis adalah sebuah kegiatan yang sangat kompleks, karena penulis harus mengendalikan bahasa pada level kalimat (struktur, tatabahasa, kosakata, tanda baca, ejaan dan pembentukan huruf) serta pada level yang lebih luas dari kalimat (mengorganisasikan dan mengintegrasikan informasi menjadi paragraf-paragraf yang kohesif dan koheren dan selanjutnya menjadi teks yang kohesif dan koheren).(Syukur, 2010)

Maksud dari pernyataan di atas, menulis adalah suatu tindakan yang dilakukan secara kompleks guna mengendalikan bahasa pada level kalimat (struktur, tatabahasa, kosakata, tanda baca, ejaan dan pembentukan huruf) dalam mengorganisasikan dan mengintegrasikan informasi menjadi paragraf-paragraf yang kohesif dan koheren.

Menurut Janet Emig, "writing is unique to learning because it originates a verbal construct that is graphically recorded."(Taiping Xu, 2015) Menulis adalah sesuatu keunikan untuk belajar karena berasal dari sebuah konstruksi lisan yang direkam secara grafis. Maksdunya ialah menulis juga merupakan keterampilan sangat signifikan dalam belajar berbahasa, karena melibatkan proses memilih, menggabungkan dan mengatur kata-kata individu untuk mengembangkan ide. 
Melalui tulisan argumentasi, siswa dapat menuangkan idenya terhadap suatu yang dianggap benar. Dengan menggunakan data berupa fakta-fakta siswa akan lebih dapat meyakinkan orang lain atas kebenaran pendapat yang akan dikemukakanya.

Selain itu, Enduran, S \& Maria menyatakan bahwa setiap siswa dalam suatu pelajaran sangat membutuhkan argumentasi, yang tujuannya untuk memperkuat pemahaman diri seorang siswa tersebut.( Taiping $\mathrm{Xu}$, 2015) Argumentasi dipandang perlu karena dalam kegiatan akademis, siswa sering mengemban tugas untuk mengajukan pendapat atau pandangan terhadap sesuatu, misalnya memberikan argumentasi dalam menjawab soal-soal esai, atau dalam membuat hasil percobaan atau pengamatan. Argumentasi juga merupakan karangan yang mengemukakan sesuatu dengan memberikan alasan, contoh, dan bukti yang kuat atau meyakinkan sehingga pembaca terpengaruh dan membenarkan pendapat, gagasan dan keyakinan tersebut.(Ahmad Ridhani, 2015) Berhasil tidaknya penulisan argumentasi terletak pada kemahiran dan keahlian penulisnya, apakah ia sanggup meyakinkan pembaca bahwa hal yang dikemukakanya dan keputusan yang diambilnya merupakan kebenaran.

Kemampuan menulis argumentasi adalah kesanggupan seseorang mengungkapkan ide dan gagasan secara tertulis yang bertujuan untuk meyakinkan pembaca dengan mengemukakan alasan yang disertai dengan bukti atau fakta, terdapat alur tulisan (organisasi isi), susunan tata bahasa (penggunaan kata depan, penghubung, dan kata tugas dengan tepat), serta tanda baca dan ejaan yang tepat atau baik.

Disamping dapat menulis argumentasi, seseorang juga dapat menuangkan idenya secara kritis, dalam hal ini yatu berpikir kritis. Johnson berpendapat bahwa berpikir kritis adalah sebuah proses sistematis yang memungkinkan siswa untuk merumuskan dan mengevaluasi keyakinan dan pemdapat mereka sendiri.(Ahmad Ridhani, 2015) Maksud dari pendapat tersebut, berpikir kritis dalah sebuah proses terorganisasi yang memungkinkan siswa mengevaluasi bukti, asumsi, logika dan bahasa yang mendasari pernyataan orang lain.

Dijelaskan lebih lanjut oleh Wanda Teays tentang berpikir kritits atau critical thinking:

"When studying critical thingking,you acquire skiils and tools to construct or take apart argument, examine data, weigh evidence, read more carefully, subject your own reasoning to assessemnet, reflect on your beliefs, and articulate your own ideas clearly and defensibly. The result is that you think with more care and precision.(Wanda Teays, 2006)"

Dari pernyataan tersebut, dapat diartikan bahwa ketika mempelajari berpikir kritis, akan diperoleh keterampilan dan perlengkapan untuk mengkontruksi atau mengesampingkan pendapat-pendapat, meneliti data-data, mempertimbangkan fakta, membaca lebih teliti, mengutarakan pendapat pribadi unutk sebuah penaksiran, refleksi dari sebuah keyakinan, dan membicarakan ide-ide sendiri secara jelas dan penuh pembelaan. Hasilnya adalah dapat berpikir dengan lebih saksama dan teliti.

Menurut Robert Ennis, berpikir dapat dirumuskan dalam aktivitas-aktivitas kritis, seperti: (1) Mencari jawaban yang jelas dari setiap pertanyaan; (2) Mencari alasan atau argumen;(3) Berusaha mengetahui informasi dengan tepat; (4) Memakai sumber yang memiliki kredibilitas dan menyebutkannya; (5) memperhatikan situasi dan kondisi secara keseluruhan; (6) Berusaha tetap relevan dengan ide utama; (7) Memahami tujuan yang asli dan mendasar; (8) Mencari alternative jawaban; (9) Bersikap dan berpikir terbuka; (10) Mengambil sikap ketika ada bukti yang cukup untuk melakukan sesuatu; (11) Mencari penjelasan sebanyak mungkin apabila memungkinkan; (12) Berpikir dan 
bersikap secara sistematis dan teratur dengan memperhatikan bagian-bagian dari keseluruhan masalah.(Wanda Teays, 2006)

Dijelaskan lebih lanjut bahwa indikator berpikir kritis dalam aktivitas kritis nomor 1 adalah ammpu merumskan pokok-pokok permasalahan. Indikator yang berasal dalam aktivitas kritis nomor 3,4 dan 7 adalah mampu mengungkapkan fakta yang dibutuhkan dalam menyelesaikan suatu masalah. Indokator yang berasal dari aktivitas kritis nomor 2, 4, 6 dan 12 adalah mampu memilih argumen yang logis, relevan dan akurat. Indikator yang ditirunkan dari aktivitas nomor 5 dan 9 adalah mampu menentukan akibat dari suatu pernyataan yang diambil sebagai suatu keputusan.

Johnson dan Lamb dalam Juita, menyatakan bahwa berpikir kritis merupakan sebuah proses yang terarah dan jelas yang digunakan dalam kegiatan mental seperti memecahkan masalah, mengambil keputusan, membujuk, menganalisis asumsi, dan melakukan penelitian ilmiah.(Yulia, 2015) Berpikir kritis meliputi berpikir logis dan beralasan berkaitan dengan keterampilan seperti membandingkan, menggolongkan, mengurutkan, sebab akibat, menyusun, mengaitkan, analogi, proses berpikir deduktif, dan penyebab induktif, ramalan, rencana, membuat hipotesis, dan tinjauan kritis. Kritis berkaitan dengan ketajaman dalam menganalisis suatu hal atau persoalan dan pengambilan keputusan. Semakin tajam seseorang menganalisis suatu permasalahan maka akan semakin tajam pula keputusan yang dibuat oleh orang tersebut.

Scriven dan Paul stated, mengatakan bahwa berpikir kritis adalah sebagai berikut: "critical thingking is the intellectually disciplined process of actively and skillfully conceptualizing, applying, analyzing, and or evaluation information gathered from, or generated by observation, experience, reflection, reasoning, or communication, as a guide to belief and action (Larry, W, 2015)".

Maksud dari pernyataan terbebut, berpikir Kritis adalah proses disiplin ilmu secara aktif dan terampil konseptualisasi, menerapkan, menganalisis, dan atau evaluasi informasi yang dikumpulkan atau dihasilkan oleh pengamatan, pengalaman, refleksi, penalaran, atau komunikasi, sebagai panduan untuk keyakinan dan tindakan.

Ennis dalam Hassoubah menjelaskan bahwa berpikir kritis adalah berpikir secara beralasan dan reflektif dengan menekankan kepada pembuatan keputusan tentang apa yang harus dipercayai atau dilakukan.(Lizamuddin, 2006) Berdasarkan pejelasan tersebut, belajar berpikir kritis berarti menggunakan proses-proses mental, seperti memperhatikan, mengatagorikan, seleksi, dan menilai/memutuskan.

Dari beberapa teori tentang berpikir dapat disimpulkan bahwa berpikir kritis berarti berpikir secara tajam, tidak lekas percaya, dan selalu berusaha menemukan kesalahan atau kekeliruan dan tidak ada unsur sentimen pribadi dalam mencari kesalahan, melainkan semata-mata ingin menegakkan kebenaran. Sehingga dapat membaca pemahaman dari orang lain.

Pemahaman atau comprehension menurut Haris dan Smith adalah label yang biasanya diterapkan untuk pemerolehan makna dari bacaan. Membaca tidak terjadi tanpa pemahaman dan pemahaman bacaan tidak tercapai jika tidak melibatkan aktivitas berpikir,(Henry, 2008)

Pemahaman terhadap bacaan sangat bergantung pada semua aspek yang terlibat dalam proses membaca.(Kundharu, 2012) Menurut Kundharu Saddhono \& St Y. Slamet Pemahaman itu sangat dipengaruhi oleh pengalaman dan pengetahuan pembaca. Pembaca yang memiliki pengetahuan dan pengalaman yang lebih besar untuk dapat mengembangkan pemahaman kata dan konsep daripada yang lainnya. Hal tersebut disadari oleh adanya asumsi bahwa penulis pun mengungkapkan gagasannya 
menggunakan alur berpikir tertentu, dan mengikuti aturan bahasa yang berlaku.(Haryadi, 2006)

Maksud pernyataan di atas, memahami bacaan tergantung pada aspek yang terlihat dalam membaca, memahami bacaan dipengaruhi oleh pengalaman pembaca, pembaca yang memiliki pengalaman yang luas akan dapat mengembangkan pemahaman yang terdapat teks bacaan.

Haryadi mengatakan di dalam membaca pemahaman merupakan suatu proses untuk mengenali atau mengidentifikasi teks, kemudian mengingat kembali isi teks. Membaca pemahaman juga dapat berarti sebagai suatu kegiatan membuat urutan tentang uraian/ menggorganisasi isi teks, bisa mengevaluasi sekaligus dapat merespon apa yang tersurat atau yang tersirat dalam teks, sedangkan pemahaman berhubungan laras dengan kecepatan. Pemahaman atau comprehension, adalah kemampuan membaca untuk mengerti: ide pokok, detail penting dan seluruh pengertian. Membaca pemahaman (reading for understanding) yang dimaksudkan di sini adalah sejenis membaca yang bertujuan untuk memahami: 1) standar atau norma-norma sesastra (letery standards), 2) resensi kritis (ctitical review), 3) drama tulis (printed drama), dan 4) pola-pola fiksi (pattems of fiction).

Yoakam mengatakan, membaca pemahaman merupakan membaca dengan cara memahami materi bacaan yang melibatkan asosiasi (kaitan) yang benar antara makna dan lambang (simbol) kata, penilaian konteks makna yang diduga ada, pemilihan makna yang benar, organisasi gagasan ketika materi bacaan dibaca, penyimpanan gagasan, dan pemakaiannya dalam berbagai aktivitas sekarang atau mendatang. Menurutnya, membaca pemahaman berbeda dengan membaca permulaan. Dengan membaca yang terdapat beberapa indikasi pemahaman yang perlu diperhatikan guna menentukan ketercapaian tujuan pembelajaran.

\section{METODE}

Penelitian dilakukan di SDN (01, 03, 04, 05, 07, 08) Banyumudal Kota Pemalang. Metode penelitian yang digunakan adalah korelasional. Populasi dalam penelitian ini adalah siswa kelas V SDN $(01,03,04,05,07,08)$ Banyumudal Kota Pemalang. Sampel penelitian ini berjumlah 60 (enam puluh) orang dengan teknik clutser sampling.

Pengumpulan data dilakukan dengan menggunakan tiga instrumen pengumpulan data, yaitu instrumen berpikir kritis, instrumen membaca pemahaman dan tes menulis untuk mengukur kemampuan menulis argumentasi. Instrumen berpikir kritis dan tes membaca pemahaman diberikan kepada sampel penelitian. Sampel merespon instrumen yang diberikan, sedangkan pengukuran kemampuan menulis argumentasi dilakukan dengan tes tertulis (menulis argumentasi).

Data hasil kemampuan menulis argumentasi diperoleh melalui tes keterampilan menulis argumentasi. Dari tes keterampilan menulis argumentasi tersebut data yang masuk berjumlah 60 orang dengan skor total 1138. Berdasarkan hasil perhitungan, diperoleh nilai rata-rata skor variabel kemampuan menulis argumentasi $=18,9667$, modus $=$ dan 19, median $=19$, dan standar deviasi $=2,816$. Dilihat secara empirik skor terendah 13 dan skor tertinggi 26 . Rentang skor teoritik terendah yang mungkin dicapai responden adalah 0 dan tertinggi 26. Inilah yang dianalisis, baik secara deskriptif maupun secara inferensial. Agar uji hipotesis dapat dilakukan, maka dilakukan uji normalitas dan uji homogenitas data. Teknik analisis data menggunakan teknik korelasi sederhana dan korelasi ganda serta teknik regresi sederhana dan ganda. 


\section{HASIL DAN PEMBAHASAN \\ Hasil}

Hasil analisis regresi ganda antara berpikir kritis dan membaca pemahaman dan kemampuan menulis argumentasi atas membaca pemahaman diperoleh harga koefesien arah regresi ganda dengan konstanta a sebesar 5,153 koesien arah regresinya $\mathrm{b}_{1}$ sebesar 0,164 untuk berpikir kritis ,dan $b_{2}$ sebesar 0,187 untuk membaca pemahaman. Dengan demikian bentuk hubungan antara kedua variabel bebas secara bersama-sama dengan variabel terikat tersebut dapat digambarkan melalui persamaan regresi $\hat{\mathrm{Y}}=$ $5,153+0,164 X_{1}+0,187 X_{2}$.

\section{Pembahasan}

Dalam penelitian ini ditemukan hubungan positif antara berpikir kritis $\left(\mathrm{x}_{1}\right)$ dan membaca pemahaman $\left(\mathrm{x}_{2}\right)$ baik secara sendiri-sendiri maupun bersama-sama dengan kemampuan menulis argumentasi. Berpikir kritis $\left(\mathrm{x}_{1}\right)$ perlu dikembangkan dan diintegrasikan dalam pendidikan yaitu melalui rasa percaya diri, ketekunan, kerja keras, menerima tantangan baru. Dalam hal ini guru hendaknya menumbuhkan semangat, motivasi serta memberikan umpan yang sesuai dengan kebutuhan siswa. Kemampuan menulis argumentasi perlu ditingkatkan dengan jalan memberikan pembelajaran yang mampu meningkatkan kemampuan berpikir siswa, sehingga siswa mampu meningkatkan pengetahuan yang dimilikinya. Selanjutnya, dalam pembelajaran bahasa Indonesia, guru harus melakukan pembelajaran yang bervariasi dan bermakna sehingga konsep membaca dapat dipahami oleh siswa.

Hasil penelitian dapat diuraikan sebagai berikut: (1) terdapat hubungan positif antara berpikir kritis dengan hasil kemampuan menulis argumentasi dengan $r=0,421$, koefesien determinasi 0,1772 dengan regresi $\hat{\mathrm{Y}}=15,106+0,114 \mathrm{x}_{1}$ yang berarti apabila berfikir kritis ditingkatkan satu poin, maka kemampuan menulis argumentasi cenderung meningkat sebesar 0,114 pada konstanta 15,106. (2) membaca pemahaman dengan kemampuan menulis argumentasi dengan $r=0,439$, koefesien determinasi 0,1927 dengan regresi $\hat{Y}=13,18+0,516 X_{2}$ yang berarti apabila membaca pemahaman ditingkatkan satu poin, maka kemampuan menulis argumentasi cenderung meningkat sebesar 0,516 poin pada konstanta 13,18. (3) terdapat hubungan positif antara berpikir kritis dan membaca pemahaman secara bersama-sama dengan kemampuan menulis argumentasi dengan $r=0,559$, koefesien determinasi 0,3124 dengan regresi ganda $\hat{Y}=4,428+0,096 X_{1}+0,445 X_{2}$ yang berarti setiap perubahan satu skor pada berfikir kritis dan membaca pemahaman menyebabkan peningkatan kemampuan menulis argumentasi sebesar 0,096 pada kosntanta sebesar 0,445 .

\section{PENUTUP}

Berdasarkan hasil penelitian dan analisis data dalam penelitian ini dapat disimpulkan bahwa: 1) terdapat hubungan positif antara berpikir kritis $\left(\mathrm{X}_{1}\right)$ dengan kemampuan menulis argumentasi (Y) pada siswa kelas V SDN Banyumudal-Pemalang, 2) terdapat hubungan positif antara membaca pemahaman $\left(X_{2}\right)$ dengan kemampuan menulis argumentasi (Y) pada siswa kelas V SDN Banyumudal-Pemalang, 3) terdapat hubungan positif antara variabel berpikir kritis dan membaca pemahaman secara bersama-sama dengan variabel kemampuan menulis argumentasi pada siswa kelas $\mathrm{V}$ SDN Banyumudal-Pemalang. Temuan tersebut menunjukkan bahwa berpikir kritis dan membaca pemahaman adalah faktor yang mempunyai hubungan dengan kemampuan menulis argumentasi. 
Berdasarkan temuan penelitian, maka ada beberapa saran sehubungan dengan peningkatan hasil belajar bahasa Indonesia (1) berpiir kritis perlu dikembangkan dan diintegrasikan dalam pendidikan yaitu melalui rasa percaya diri, ketekunan, kerja keras, menerima tantangan baru, (2) Dalam proses pembelajaran guru hendaknya mengetahui berpikir kritis yang dimiliki oleh siswa. Dalam hal ini guru hendaknya menumbuhkan semangat, motivasi serta memberikan umpan yang sesuai dengan kebutuhan siswa. (3) Hasil belajar bahasa indonesia perlu ditingkatkan dengan jalan memberikan pembelajaran yang mampu meningkatkan kemampuan berpikir siswa dengan meningkatkan kemampuan menulis argumentasi, sehingga siswa mampu meningkatkan pengetahuan yang dimilikinya.(4) Dalam pembelajaran bahasa Indonesia guru harus melakukan pembelajaran yang bervariasi dan bermakna sehingga konsep dapat dipahami oleh siswa.

\section{DAFTAR PUSTAKA}

Abdul Chaer. (2011). Tata Bahasa Praktis Bahasa Indonesia. Jakarta: Rineka Cipta Jujun, S. (2005). Filsafat Ilmu: Sebuah Pengantar Populer . Jakarta : Sinar Harapan Syukur, G. (2010). Pembelajaran Keterampilan Berbahasa dengan Pendekatan Komunikatif Interaktif. Bandung :PT. Refika Aditama

Taiping Xu. (2015), Qualitative Research on the Using of Writing Workshop Techniques in English Writing Class". Journal of Language Teaching and Research ( Vol 6, No 5) Diambil kembali dari http://web.b.ebscohost.com

Ahmad Ridhani. (2015, Desember 2). , Tipe Argumen Wacana Argumentasi Tulis Siswa Sekolah Dasar Kelas Tinggi (Vol.12 Cetakan ke 1) Diambil kembali http://jurnal.unimed.ac.id/

Wanda Teays, (2006), Second Thoughts: Critical thingking for A Diserve Society (New York: Mc. Graw Hill)

Yulia A.S, (2015). , Efektifitas Pembelajaran Problem Based Learning (PBL) dalam Meningkatkan Prestasi Belajar, Kemampuan Berpikir Kritis, dan Berpikir Kreatif Siswa Kelas VIII SMPI Sabilillah Diambil dari http://palimpsest.fisip.unair.ac.id

Larry W. Howard, et al (2015, November 21). Teaching Critical Thinking Skills: Ability, Motivation, Intervention, and the Pygmalion Effect. Journal of Language Teaching and Research Diambil dari http://web.b.ebscohost.com/

Lizamuddin, M. (2006). Pijar - Pijar Pemikiran Bahasa dan Budaya. Jakarta: Diadit Media 